\title{
PENGARUH PENERAPAN E-KINERJA DAN INTEGRITAS TERHADAP KINERJA PEGAWAI
}

\author{
Sisi Wahyuni \\ Jurusan Ilmu Administrasi Negara, Fakultas Ilmu Sosial, Universitas Negeri Padang \\ sisiwahyuni32@gmail.com
}

\begin{abstract}
This study aimed to identify the effect of the E-Kinerja (E-Performance) application and integrity on employee performance in OPD Payakumbuh City. This study used a quantitative research method. The research variable of this study consisted of independent variables, namely E-performance and integrity, while the dependent variable was employee performance. The population of this study were OPD employees in Payakumbuh, and the sample of this study was 97 respondents who were determined using the Slovin formula with a significant level of $10 \%$. The data in this study were collected through questionnaires that were distributed to respondents using a Likert measurement scale. The analysis of this study used multiple linear regression test. The results showed that eperformance and integrity had significant influences on employee performance in $O P D$ Payakumbuh City.
\end{abstract}

Keywords: E-Performance, integrity, employee performance

\section{Pendahuluan}

Dalam menjalankan pemerintah yang baik, pemantauan kinerja dan integritas sangat diperlukan agar tugas yang telah diberikan kepada pegawai dapat dikerjakan semaksimal dan sebaik mungkin. Dengan pesatnya perkembangan zaman saat ini, banyak teknologi-teknologi yang dapat mempermudah kegiatan sehari-hari, dan tak dapat dipungkiri pula kegiatan yang menyangkut pemerintahan. Dengan kemajuan teknologi yang ada pemerintah dapat memanfaatkannya dengan penggunaan sistem informasi berbasis web atau aplikasi dalam memantau kinerja harian pegawai. Pemantauan kinerja berbasis sistem aplikasi atau web merupakan salah satu bentuk dari penerapan e-government. Penilaian kinerja berbasis teknologi juga dapat mengurangi biaya administrasi dan membuat penilaian menjadi lebih efektif dan efisien.

Dengan penggunaan sistem ini pemerintah dapat memantau kinerja pegawai setiap harinya, mulai dari absen harian, pencatatan aktivitas harian, penilaian SKP, 
penilaian perilaku kerja dan penilaian prestasi kerja. Penggunaan aplikasi kinerja ini juga dapat memperlihatkan tunjangan tambahan penghasilan, tunjangan biaya hidup, tunjangan hari raya sesuai dengan kinerja yang telah diinputkan sebelumnya. Kota Payakumbuh telah menggunakan system penilaian kinerja berbasis web pada tahun 2018, menggunakan APIK yang mana pemerintah Kota Payakumbuh saat itu berpedoman pada Tanggerang Selatan. Sebagaimana instruksi Presiden Nomor 3 Tahun 2003 Tentang Kebijakan dan Strategi Nasional Pengembangan EGovernment, Kota Payakumbuh telah mengganti penggunaan APIK dengan menggunaan E-Kinerja.

Penggunaan aplikasi E-Kinerja baik langsung ataupun tidak langsung dapat mempengaruhi kinerja dari seorang pegawai. Seperti dari hasil wawancara dengan seorang pegawai di DPMPTSP Kota Payakumbuh bahwa dengan banyaknya pekerjaan yang harus dilakukan dan kesibukan dalam pelayanan kepada masyarakat, mereka juga harus memberikan pelaporan kinerja. Pelaporan kinerja ketika diinputkan harus disertai dengan bukti berupa dokumentasi maupun dokumen hasil kerja pegawai pada waktu tersebut.

Selain peningkatan kinerja yang harus ditingkatkan oleh pegawai, integritas adalah salah satu dari unsur penting yang harus ditingkatkan oleh pegawai. Kurangnya integritas seorang pegawai dapat menghambat hasil kerja dan dapat mempengaruhi organisasi dalam mencapai tujuannya. Dengan demikian peningkatan kinerja dan integritas harus sejalan agar hasil kerja yang didapatkan bisa seoptimal mungkin. Sikap disiplin, dan selalu menaati nilai-nilai yang ada dapat meningkatkan kinerja pegawai, dan memberikan hasil kerja yang optimal. Integritas itu sendiri merupakan pola pikir dan karakter pegawai yang sesuai dengan nilai-nilai, etika dan moral pegawai dalam menjalankan tugasnya untuk meningkatkan kinerja pegawai.

Integritas merupakan pola pikir yang harus sesuai dengan tindakan. Contohnya saja sesuai dengan hasil wawancara yang telah dilakukan dengan salah satu pegawai DPMPTSP Kota Payakumbuh, pegawai yang sudah terbiasa mengulur pekerjaan karena berpikir pekerjaan masih bisa diselesaikan di waktu yang lain, dimana pola pikir mengedepankan pekerjaan di atas keperluan pribadi di saat bertugas harus dapat direalisasikan, tidak hanya sebatas pola pikir saja. Selain dari diri sendiri integritas juga dapat dipengaruhi oleh lingkungan sekitar pegawai. Fokus pada pekerjaan yang sedang atau ingin dilakukan dapat membantu mempengaruhi integritas dalam bekerja, lingkungan yang kurang kondusif, seperti banyaknya gangguan dalam bekerja atau terlibat dengan lingkungan yang dapat mengalihkan pikiran dari pekerjaan bisa mempengaruhi pegawai baik secara langsung maupun secara tidak langsung. Selain dari faktor lingkungan hingga fokus para pegawai dalam bekerja, masih banyak yang dapat mempengaruhi integritas baik internal maupun eksternal. Pegawai yang berada pada lingkungan yang telah 
terbiasa dalam menunda pekerjaan dapat terpengaruhi jika pegawai tersebut tidak dapat memegang teguh integritas yang dimilikinya.

\section{Tinjauan Kepustakaan}

\section{Kinerja Pegawai}

Kinerja menurut Rivai and Basri (2005) merupakan sebuah hasil maupun tingkat keberhasilan pegawai dalam melaksanakan tugasnya secara keseluruhan selama periode tertentu. Kinerja menurut Mahmudi (2005) merupakan sebuah konstruk bersifat multidimensional dengan berbagai variasi pengukuran tergantung dari faktor pembentuk kinerja. Hasil dari sebuah pekerjaan yang dilakukan inilah yang merupakan pengertian sederhana dari kinerja pegawai. Pengertian lain mengenai kinerja juga disampaikan oleh Marwansyah (2012) yang berpendapat bahwa kinerja adalah suatu prestasi atau pecapaian yang telah dicapai pegawai dalam menyelesaikan tugas atau pekerjaan yang telah diamanahkan kepadanya. Semakin besar kemampuan pegawai dalam menjalankan pekerjaan atau tugasnya maka seakin besar pula kinerja yang dapat dihasilkan, dikarenakan itu penempatan pegawai dalam posisi yang ia kuasai haruslah tepat.

Penilaian kinerja merupakan penilaian prestasi yang dilakukan secara formal dan sistematis dalam satu periode. Banyak indikator yang dapat mengukur tingkat kinerja pegawai, salah satunya adalah indikator yang dikemukakan oleh Wibowo (2015), yang menyebutkan bahwa penilaian kinerja harus dilakukan secara relvan dan signifikan dengan mengklasifikasikan beberapa indikator untuk menilai kinerja yaitu:

a. Produktivitas; artinya berapa banyak output atau hasil kerja yang bisa dihasilkan seorang pegawai selama bekerja.

b. Kualitas; artinya seberapa bagus hasil kerja yang telah dilakukan oleh pegwai dalam menyelesaikan pekerjaanya.

c. Ketepatan waktu; artinya pegawai dapat melaksanakan tugas dan kewajibannya secara tepat waktu.

d. Cycle Time; artinya berapa lama bagi seorang pegawai berpindah dari satu pekerjaan ke pekerjaan lainnya.

\section{E-Kinerja dan Pengaruhnya Terhadap Kinerja}

Menurut Mukti (2019) E-Kinerja adalah aplikasi buatan yang dikhususkan untuk memantau dan menilai kinerja dari pegawai secara langsung dengan cara memasukkan data kerja harian kedalam software untuk mendapatkan persetujuan dari atasan. Disamping itu menurut Putri (2014) E-Kinerja merupakan suatu aplikasi yang berbasis web yang dipergunakan untuk menganilisi jabatan, beban kerja, unit maupun satuan kerja organisasi yang merupakan dasar untuk menghitung prestasi kerja dan pemberian intensif kerja. Menurut Indrajit (2006) E-Kinerja yang 
merupakan salah satu perwujutan dari e-government dapat juga dipergunakan untuk meningkatkan kinerja pegawai dan kesejahteraan pegawai baik yang bekerja dengan pemerintahan maupun yang tidak. Penerapan e-kinerja harus dilihat dari kemanfaatan dari aplikasi dan juga kemurahan dalam penggunaan aplikasi tersebut. Hal ini menjadi indikator yang penting dalam menilai e-kinerja yang merupakan salah satu dari penerapan e-government.

Menurut hasil penelitian yang dilakukan oleh Nurhayati (2019) menunjukkan bahwa penerapan e-kinerja memiliki pengaruh positif serta signifikan terhadap kinerja. Hasil yang sama ditunjukkan oleh penelitian yang dilakukan oleh Putri et al. (2014) yang menunjukkan bahwa e-kinerja berpengaruh terhadap kinerja pegawai. Dari hasil penelitian yang dilakukan Mukti et al. (2019) juga mengatakan bahwa penerapan e-kinerja juga berpengaruh positif dan signifikan terhadap prestasi kerja.

\section{Integritas dan Pengaruhnya Terhadap Kinerja}

Menurut Mulyadi Wetik (2018) integritas merupakan keharusan diamana pegawai diharuskan untuk dapat bersikap jujur, berani, bijaksana dan bertanggungjawab. Terlepas dari sifat seorang pegawai mereka harus mengikuti norma-norma yang berlaku hal ini dapat dilihat dari teori yang dikemukakan oleh Trevinyo yang berpendapat bahwa integritas juga erat kaitannya dengan moral yang bersifat obyektif, terlepas dari kerangka individu, sosial dan organisasi (Trevinyo Rodriguez dalam Yulianti 2015). Semakin baik integritas yang dimiliki seseorang semakin baik juga kinerja yang dihasilkan oleh pegawai dan integritas juga dapat memperlihatkan perilaku dari seorang pegawai. Integritas juga dapat memprediksi perilaku-perilaku seperti korupsi yang telah marak terjadi di Indonesia (Syamsir 2014). Dapat dilihat dari berbagai defenisi yang dikemukakan dalam mengartikan integritas, bahwa integritas seolah berperan sangat penting dalam kinerja yang dapat diberikan pegawai, dan juga dapat meprediksi perilaku seorang pegawai hanya dengan melihat integritas pegawai. Adanya kesesuaian hati dan pikiran serta selarasnya ucapan dengan tindakan merupakan salah satu defenisi integritas yang dikemukakan oleh Syamsir dan Embi (2020).

Dari teori dan defenisi yang telah dijelaskan di atas dapat dilihat bahwa integritas dapat mempengaruhi hasil kerja, prestasi maupun kinerja dari pegawai. Pegawai yang berani dalam menjalankan tugas, pegawai yang jujur dalam bekerja, bijaksana dalam mengambil keputusan dan menghadapi situasi serta pegawai yang bertanggung jawab dengan semua pekerjaan yang diembankan padanya akan memiliki kinerja atau hasil kerja yang juga baik. Untuk melakukan penelitian ini, ada beberapa indikator yang dapat dijadikan pedoman untuk mengukur integritas seorang pegawai yaitu dilihat dari kejujuran dan transparansi seorang pegawai

melakukan pekerjaannya, kebijaksanaan pegawai dalam pekerjaannya dan 
tanggung jawab seseorang terhadap apa yang telah diamanahkan terhadapnya yaitu pekerjaannya (Yulianti 2015).

Integritas dan kinerja memiliki pengaruh, bisa terlihat dari hasil penelitian yang telah dilakukan Salwa (2018) bahwa integritas memiliki pengaruh positif dan signifikan terhadap kinerja pegawai. Penelitian yang dilakukan oleh Yusnaena and Syahril (2013) juga menunjukkan adanya pengaruh yang signifikan antara integritas terhadap kinerja. Sama halnya dengan penelitian yang dilakukan oleh Wetik et al. (2018) yang menyatakan integritas berpengaruh positif dan signifikan terhadap kinerja pegawai. Terdapat banyak penelitian yang membuktikan bahwa terdapatnya pengaruh antara integritas dan kinerja. Selain penelitian di atas juga terdapat dalam penelitian dari Riri dan Syamsir (2020). Semakin baik integritas pegawai dalam pekerjaannya semakin baik pula kinerja yang dapat dihasilkan. Masih banyak lagi hasil penelitian yang menunjukkan bahwa integritas berpengaruh signifikan terhadap kinerja pegawai. Febrina dan Syamsir (2020), Wahyuni dan Syamsir (2020), serta Rosmi dan Syamsir (2020a dan 2020b), contohnya, dalam temuan penelitian mereka di lingkungan PNS di Kota Sawahlunto, Kabupaten Kerinci, dan Kabupaten Bungo mendapati bahwa integritas dan variabel lainnya berpengaruh signfikan terhadap kinerja pegawai.

\section{Metode Penelitian}

Penelitian ini menggunakan penelitian kuantitatif dengan menggunakan perhitungan angka-angka dengan menggunakan analisis statistik. Lokasi Penelitian adalah beberapa OPD yang berada di Kota Payakumbuh. Secara umum penelitian kuantitatif adalah penelitian dengan menggunakan metode untuk menguji teoriteori tertentu dengan cara meneliti hubungan antara variabel. Variabel ini diukur dengan instrumen penelitian sehingga data yang terdiri dari angka-angka yang dapat dianalisis berdasarkan prosedur statistik. Variabel penelitian ini menggunakan variabel bebas yaitu E-kinerja dan integritas dan variabel terikat penelitian ini adalah kinerja pegawai.

Dalam penelitian ini pegawai OPD yang ada di Kota Payakumbuh merupakan populasi yang diteliti dengan sampel penelitian sebanyak 97 responden, dimana telah ditentukan menggunakan rumus Slovin dengan tingkat signifikan $10 \%$. Teknik dalam mengumpulkan data penelitian ini dilakukan dengan membagikan kuesioner (angket) kepada responden. Penelitian yang dilakukan ini memakai analisis uji regresi linear berganda yang didasari pengolahan data dengan penggunaan program SPSS (Statistic Programme for Social Science) versi 24.0.

\section{Hasil dan Pembahasan}

Dari rumusan masalah yang tertera di atas dalam bagian pendahuluan ada dua rumusan masalah yaitu apakah terdapat pengaruh signifikan dari penerapan aplikasi 
e-kinerja terhadap kinerja pegawai? dan apakah terdapat pengaruh signifikan dari integritas yang dimiliki pegawai terhadap kinerja pegawai yang ada di OPD Kota Payakumbuh? Setelah melakukan pengumpulan data dari penelitian yang diambil dari penyebaran angket ke beberapa pegawai di OPD Kota Payakumbuh, dapat terlihat hasil analisis data sesuai dengan tujuan penelitian. Tabel dari uji analisis linear berganda penelitian ini dapat dilihat dibawah ini :

Tabel 1. Kontribusi Variabel E-Kinerja (X1) Terhadap Kinerja Pegawai (Y) Model Summary ${ }^{b}$

\begin{tabular}{|c|c|c|c|c|}
\hline Model & $\mathbf{R}$ & R Square & Adjusted R Square & $\begin{array}{l}\text { Std. Error of the } \\
\text { Estimate }\end{array}$ \\
\hline 1 & $.625^{\mathrm{a}}$ & .391 & .384 & 5.281 \\
\hline
\end{tabular}

Sesuai dengan hasil tabel yang ada di atas dapat terlihat nilai Adjusted $R$ Square sebesar 0,384, dimana terlihat besar pengaruh variabel e-kinerja terhadap kinerja pegawai pada OPD Kota Payakumbuh sebesar 38,4\%. Di luar itu sebanyak $61,6 \%$ ada faktor lain yang mempengaruhi variabel tersebut.

Tabel 2. Hasil Uji Anova Variabel E-Kinerja (X1) Terhadap Kinerja Pegawai (Y)

ANOVA ${ }^{b}$

\begin{tabular}{llccccc}
\hline \multicolumn{2}{l}{ Model } & $\begin{array}{c}\text { Sum of } \\
\text { Squares }\end{array}$ & df & $\begin{array}{c}\text { Mean } \\
\text { Square }\end{array}$ & F & Sig. \\
\hline $1 \quad$ Regression & 1699.895 & 1 & 1699.895 & 60.950 & $.000^{\mathrm{a}}$ \\
& Residual & 2649.549 & 95 & 27.890 & & \\
& Total & 4349.443 & 96 & & & \\
\hline
\end{tabular}

a. Predictors: (Constant), E-kinerja

b. Dependent Variable: Kinerja

Berdasarkan hasil tabel yang tertera di atas bisa dilihat besar nilai signifikansi pengaruh variabel e-kinerja terhadap kinerja pegawai di OPD Kota Payakumbuh adalah 0,000, dimana signifikansi nilainya lebih kecil dari 0,05. Dan bisa dikatakan bahwa variabel e-kinerja memiliki pengaruh signifikan terhadap kinerja pegawai pada di Organisasi Perangkat Daerah Kota Payakumbuh.

Berikut hasil tabel yang ditunjukkan setelah mengolah data untuk menguji secara parsial untuk mengetahui pengaruh variabel Integritas dan Kinerja Pegawai 
Tabel 3. Kontribusi Variabel Integritas (X2) Terhadap Kinerja Pegawai (Y)

Model Summary

\begin{tabular}{lcccc}
\hline Model & R & R Square Adjusted R Square & $\begin{array}{c}\text { Std. Error of the } \\
\text { Estimate }\end{array}$ \\
\hline 1 & $.526^{\mathrm{a}}$ & .277 & .269 & 5.753 \\
\hline
\end{tabular}

a. Predictors: (Constant), Integritas

b. Dependent Variable: Kinerja

Sesuai dengan output tabel ini bisa terlihat angka dari Adjusted $R$ Square sebanyak 0,269, dimana besar pengaruh variabel integritas terhadap kinerja pegawai pada OPD Kota Payakumbuh sebanyak 26,9\%. Lebihanya sebanyak $73,1 \%$ ada faktor lain yang tidak diteliti mepengaruhi variabel tersebut.

\section{Tabel 4. Hasil Uji Anova Variabel Integritas (X2) Terhadap Kinerja Pegawai (Y)}

\begin{tabular}{|c|c|c|c|c|c|c|}
\hline \multicolumn{7}{|c|}{ ANOVA $^{b}$} \\
\hline Model & & Sum of Squares & df & $\begin{array}{c}\text { Mean } \\
\text { Square }\end{array}$ & $\mathbf{F}$ & Sig. \\
\hline 1 & Regression & 1204.998 & 1 & 1204.998 & 36.405 & $.000^{\mathrm{a}}$ \\
\hline & Residual & 3144.445 & 95 & 33.099 & & \\
\hline & Total & 4349.443 & 96 & & & \\
\hline
\end{tabular}

Sesuai hasil output tabel di atas bisa diketahui nilai signifikansi pengaruh variabel e-kinerja terhadap kinerja pegawai di OPD Kota Payakumbuh adalah 0,000, yang mana nilai signifikansi ini teruji kecil dari 0,05. Sehingga bisa dikatakan variabel integritas dapat berpengaruh terhadap kinerja pegawai pada di OPD Kota Payakumbuh.

Berikut hasil tabel yang ditunjukkan setelah pengolahan data untuk menguji secara parsial untuk mengetahui pengaruh variabel e-kinerja dan integritas terhadap kinerja pegawai di OPD Kota Payakumbuh. 
Tabel 5. Kontribusi Variabel E-Kinerja (X1) dan Integritas (X2) Terhadap Kinerja (Y)

\begin{tabular}{lccccc}
\multicolumn{6}{c}{ Model Summary } \\
\hline Model & R & R Square & $\begin{array}{c}\text { Adjusted R } \\
\text { Square }\end{array}$ & $\begin{array}{c}\text { Std. Error of the } \\
\text { Estimate }\end{array}$ \\
\hline 1 & $.687^{\mathrm{a}}$ & .472 & & .461 & 4.942 \\
\hline
\end{tabular}

a. Predictors: (Constant), integritas, e_Kinerja

Sesuai dengan hasil output yang tertera diatas dapat terlihat nilai Adjusted $\mathrm{R}$ Square sebesar 0,461, diana besar pengaruh dari e-kinerja dan integritas terhadap kinerja sebanyak $46,1 \%$. lebihnya sebanyak $53,9 \%$ ada faktor lain yang tidak diteliti mempengaruhi variabel tersebut.

Tabel 6. Hasil Uji Anova (F) Variabel E-Kinerja (X1) dan Integritas (X2) Terhadap Kinerja (Y)

\begin{tabular}{ccccccc}
\multicolumn{7}{c}{ ANOVA $^{\mathbf{b}}$} \\
\hline \multicolumn{1}{c}{ Model } & Sum of & & & & \\
Squares & df & Mean Square & F & Sig. \\
\hline & Regression & 2053.601 & 2 & 1026.800 & 42.041 & $.000^{\mathrm{a}}$ \\
& Residual & 2295.842 & 94 & 24.424 & & \\
& Total & 4349.443 & 96 & & & \\
\hline
\end{tabular}

a. Predictors: (Constant), integritas, e_Kinerja

b. Dependent Variable: kinerja

Sesuai hasil output tabel di atas dapat terlihat nilai signifikan pengaruh variabel e-kinerja dan integritas terhadap kinerja pegawai di OPD Kota Payakumbuh adalah 0,000. Artinya signifikansi uji nilainya yang kecil dari 0,05 membuktikan ada terdapat pengaruh variabel e-kinerja dan integritas terhadap kinerja pegawai di OPD Kota Payakumbuh.

Sesuai dengan hasil penelitian yang telah dipaparkan dengan penjelasan diatas peneliti membahas tentang Pengaruh E-kinerja dan Integritas Terhadap Kinerja Pegawai di OPD Kota Payakumbuh. Hasil dari penelitian yang telah dilakukan dengan menganalisis data, dapat dilihat dan dibuktikan bahwa adanya pengaruh E-kinerja dan Integritas terhadap kinerja pegawai di OPD Kota Payakumbuh dengan besarnya nilai signifikansi semua variabel baik e-kinerja maupun integritas kecil dari 0,05, dimana yang berarti ditolaknya Ho dan diterimanya Ha. 
E-kinerja dalam penelitian ini dijabarkan menjadi beberapa indikator yaitu, kemudahan dalam penggunaan aplikasi, pencatatan target dan realisasi kerja secara elektronik dan kuantitas dan kualitas kerja. Penjabaran indikator tersebut berpedoman pada kemanfaatan dan kemudahan penggunaan aplikasi. Terbukti dari hasil penelitian bahwa adanya pengaruh signifikan dari penggunaan aplikasi ekinerja terhadap kinerja pegawai pada Organisasi Perangkat Daerah Kota Payakumbuh. Hal ini bisa dilihat dari hasil uji hipotesis yang telah dilakukan menggunakan SPSS versi 16, yang mana thitung >t tabel dengan signifikansi 0,000, dimana ditolaknya Ho dan diterimanya Ha. Pengujian R Square menghasilkan nilai sebesar 0,391 dan nilai Adjusted R Square sebesar 0,391. Hal ini menunjukkan kekuatan variabel e-kinerja terhadap kinerja pegawai pada OPD Kota Payakumbuh $38,4 \%$ dan $61,6 \%$ lebihnya ada faktor lain yang mempengaruhi.

Menurut Indrajit (2006), aplikasi e-government juga dipergunakan untuk membuat kinerja dan kesejahteraan baik para pegawai negeri ataupun karyawan pemerintah yang bekerja di sejumlah institusi sebagai pelayan masyarakat menjadi lebih baik. Dari teori tersebut dapat diketahui bahwa kinerja baik langsung ataupun tidak langsung dapat dipengaruhi oleh e-kinerja yang merupakan salah satu bentuk dari penerapan e-government. Pemantauan kinerja harian dari para pegawai melalui aplikasi memiliki kemanfaatan yang jelas untuk meningkatkan kualitas dari hasil kerja pegawai. Aplikasi penilaian ini harus memiliki fitur yang lengkap dan mudah untuk dipahami agar pegawai dapat menjalankan aplikasi tersebut tanpa kesulitan. Dan semakin baik dan bagus aplikasi yang digunakan maka semakin baik pula kualitas dari kinerja pegawai, karena pegawai dapat dipantau dengan mudah.

Penelitian ini sesuai dengan hasil penelitian yang pernah dilakukan oleh Hal ini juga oleh Komara Eka Putri dkk pada tahun 2014 yang menunjukkan bahwa ekinerja berpengaruh signifikan terhadap kinerja pegawai. Penelitian dengan hasil yang sama juga diperlihatkan dala penelitian yang dilakukan oleh Dwi Rafita Mukti dkk pada tahun 2019 dengan hasil penelitian e-kinerja berpengaruh signifikan terhadap prestasi atau kinerja pegawai. Pengaruh Integritas yang dijabarkan ke beberapa indikator yaitu, kejujuran dan transparansi, kebijaksanaan dan tanggungjawab dibuktikan dengan adanya pengaruh yang signifikan terhadap kinerja pegawai yang ada di OPD Kota Payakumbuh. Dapat dilihat dari hasil uji hipotesis yang dilakukan dengan penggunaan program SPSS versi 16 dimana $t$ hitung $>\mathrm{t}$ tabel. Variabel integritas terdapat pengaruh yang signifikan terhadap kinerja pegawai dengan signifikansi 0,000. Hasil pengolahan data menghasilkan nil $R$ Square 0,277 dan nilai Adjusted $R$ Square 0,269. Ini memperlihatkan kekuatan variabel integritas terhadap kinerja pegawai di OPD Kota Payakumbuh sebesar 26,9\% dengan sisa sebesar 73,1\% ada faktor lain.

Menurut Mulyadi (dalam Wetik, 2018) integritas merupakan dimana seseorang pegawai diminta untuk bersikap jujur, berani, bijaksana dan bertanggung 
jawab. Sikap pegawai yang bertanggung jawab atas pekerjaan yang telah ditugaskan pada dirinya akan membuat kinerja dari pegawai akan meningkat. Dari teori tersebut dapat dilihat bahwa integritas dapat mempengaruhi hasil kerja, prestasi maupun kinerja dari pegawai. Pegawai yang berani dalam menjalankan tugas, pegawai yang jujur dalam bekerja, bijaksana dalam mengambil keputusan dan menghadapi situasi serta pegawai yang bertanggung jawab dengan semua pekerjaan yang diembankan padanya akan memiliki kinerja atau hasil kerja yang juga baik.

Yusnaena dan Syahrir pada tahun 2013 pernah melakukan penelitian yang menunujukkan hasil yang berpengaruh signifikan antara integritas dan kinerja pegawai. Salwa pada tahun 2018 juga melakukan penelitian yang menunjukkan hasil yang sama. Penelitian yang dilakukan oleh Salwa menunjukkan adanya pengaruh yang signifikan oleh integritas kepada kinerja. Semakin baik dan tinggi integritas yang dimiliki oleh pegawai, maka semakin baik dan tinggi pula kinerja yang akan diperoleh. Hasil penelitian ini juga memperkuat hasil penelitian Riri dan Syamsir (2020), Febrina dan Syamsir (2020), Wahyuni dan Syamsir (2020), serta Rosmi dan Syamsir (2020a dan 2020b), yang menunjukkan bahwa integritas berpengaruh signifikan terhadap kinerja pegawai pemerintah pada beberapa instansi pemerintah di Sawahlunto, Sijunjung, Bungo, dan Kerinci.

Dari hasil penelitian dan pengujian data di atas bisa disimpulkan bahwa terdapat pengaruh yang signfikan e-kinerja dan integritas terhadap kinerja pegawai yang ada di OPD Kota Payakumbuh. Oleh karena itu disarankan kepada pegawai OPD yang ada di Kota Payakumbuh untuk lebih meningkatkan integritas dan penggunaan aplikasi e-kinerja agar kinerja yang dihasilkan juga dapat meningkat.

\section{Penutup}

Dari hasil uji data dan penelitian diatas yang telah dijelaskan sebelumnya, dapat ditarik kesimpulan bahwa :

1. Adanya pengaruh antara variabel e-kinerja (X1) terhadap kinerja pegawai yang merupakan variabel (Y) dengan hasil nilasi Adjust $R$ Square 0,384. Artinya ada pengaruh e-kinerja terhadap kinerja pegawai d OPD Kota Payakumbuh sebesar 38,4\%. Nilai signifikansi secara parsial dari variabel e-kinerja dan kinerja yang ada di OPD Kota Payakumbuh dengan total 0,000 yang menunjukkan niliai signifikansi yang kecil dari nilai 0,05 maka bisa diambil kesimpulan dengan Ho yang ditolak dan Ha diterima.

2. Terdapatnya pengaruh yang signifikan variabel integritas (X2) terhadap kinerja (Y) dengan nilai Adjust $R$ Square yang didapat sebesar 0,269. Artinya kontribusi pengaruh dari variabel integritas kepada kinerja pegawai yang ada di OPD Kota Payakumbuh ada sebesar 26,9\%. Nilai signifikasni secara parsial variable integritas dan kinerja dengan total sebesar 0,000 berarti 
memperlihatkan bahwa nilai signifikansi yang kecil dari 0,05 dan bisa disimpulkan bahwa telah ditolaknya Ho dan diterimanya Ha.

\section{DAFTAR KEPUSTAKAAN}

Febrina, D., \& Syamsir. (2020). The Influence Of Integrity And Commitment Organizational on Employee Performance. International Journal of Research and Analytical Reviews (IJRAR), 7(1), 774-779.

Indrajit, Richardaus Eko. (2006). Electronic Government. Yogyakarta: CV. Andi Offset.

Mahmudi. (2005). Manajemen Kinerja Sektor Publik. Yogyakarta: UPP AMP YKPN.

Marwansyah. (2012). Manajemen Sumber Daya Manusia. Bandung: Alfabeta.

Mukti, Dwi Rafita, Sri Wahyu Lelly Hana Setyanti, and Lilik Farida. (2019). "Penerapan Sistem Penilaian Kinerja Berbasis E-Kinerja Terhadap Prestasi Kerja Pegawai Melalui Kepuasan Kerja Sebagai Variabel Intervening Pada Dinas Kependudukan Dan Pencatatan Sipil Kabupaten Banyuwangi." EJournal Ekonomi Bisnis Dan Akuntansi 6(2):175.

Noor, Juliansyah. (2010). Metodologi Penelitian. Jakarta: Prenada Media Grup.

Nurhayati, Ema. (2019). Pengaruh Penerapan Sistem Penilaian E-Kinerja dan Kompetensi Terhadap Kinerja Pegawai di Kecamatan Semarang Timur Melalui Motivasi Sebagai Variabel Intervening. Jurnal Penelitan Ekonomi dan Bisnis 2(2):79-91.

Putri, Komara Eka, Muhammad Arfan, and Hasan Basri. (2014). Pengaruh Penerapan E-Kinerja dan Penghargaan (Reward) Terhadap Kinerja Aparatur Pengelolaan Keuangan di Lingkungan Pemerintahan Kota Banda Aceh. Jurnal Magister Akuntansi. Pascasarjana Universitas Syiah Kuala 3(4):1-10.

Rivai, Veithzal and Ahmad Fauzi Mohd. Basri. (2005). Performance Appraisal: Sistem Yang Tepat Untuk Menilai Kinerja Karyawan dan Meningkatkan Daya Saing Perusahaan. Jakarta: PT. Rajagrafindo Persada.

Rosmi, R. and Syamsir, S. (2020). The Important of Integrity Values as Corruption Prevention Measures. TEST Engineering and Management Journal, Issue: March-April 2020, Volume 83. Pp. 12043-12054. Retrived from https://testmagzine.biz/index.php/testmagzine/article/view/5819; and http://repository.unp.ac.id/id/eprint/26928

Rosmi, R. and Syamsir, S. (2020). The Influence of Integrity and Work Experience on Employee Performance. International Journal of Research and Analytical Reviews (IJRAR). March 2020, Volume 7, Issue 1. pp. 789-794. Retrived from http://www.ijrar.org/viewfull.php?p_id=IJRAR2001820; and http://repository.unp.ac.id/id/eprint/27261 
Salwa, Arfah, Away Yuwaldi, and Tabrani Mirza. 2018. Pengaruh Komitmen, Integritas Dan Kompetensi Terhadap Kinerja Pegawai Serta Dampaknya Pada Kinerja Komisi Independen Pemilihan (KIP) Aceh. Jurnal Magister Manajemen 2(1):58-67.

Syamsir. (2014). "Mewujudkan Pelayanan Publik Yang Berintegritas Melalui Pembinaan Motivasi Pelayanan Publik." Prosiding Seminar Nasional Jurusan Ilmu Administrasi Negara, FIS, UNY 2014. IAN FIS-UNY: 1-15.

Syamsir, S. and Muhamad Ali Embi. (2020). Integrity Development Through PSM For Corruption Prevention Among Public Servant. International Journal of Psychosocial Rehabilitation, Vol. 24, Issue 08, 2020. Pp. 1437-1448. Retrived from: https://www.psychosocial.com/article/PR280157/16410/; and http://repository.unp.ac.id/id/eprint/26927

Tasi, Riri and Syamsir, S. (2020). The Influence of Integrity and Loyalty on Employee Performance. International Journal of Research and Analytical Reviews (IJRAR). March 2020, Volume 7, Issue 1. pp. 774-779. Retrived from http://www.ijrar.org/viewfull.php?p_id=IJRAR2001817; and http://repository.unp.ac.id/id/eprint/27258

Wetik, Stanislaus Wembly, Baharuddin, and Hasmin Tamsah. (2018). Analisis Pengaruh Komitmen Dan Integritas Terhadap Kinerja Melalui Kompetensi Pegawai Pada Kantor Kesyahbandaran Dan Otoritas Pelabuhan Kota Manado. YUME : Journal of Management 1(3):137-51.

Wahyuni, Rahma Sri and Syamsir, S. (2020). The Influence of Integrity and Human Resource Management towards Employee Performance. International Journal of Research and Analytical Reviews (IJRAR). March 2020, Volume 7, Issue 1. pp. 780-785. Retrived from http://www.ijrar.org/viewfull.php?p_id=IJRAR2001818; http://repository.unp.ac.id/id/eprint/26939

Wibowo. (2015). Manajemen Kinerja. Jakarta: Pt. Rajagrafindo Persada.

Yulianti, Wuryanti. (2015). Pengaruh Kepemimpinan Transformasional, Integritas Perilaku Dan Kepercayaan Terhadap Pimpinan Dalam Peningkatan Kinerja SDM (Studi LKHP, BKPPD Dan BPMP Kabupaten Konawe Selatan Provinsi Sulawesi Tenggara). Jurnal Conferense In Business, Accounting And Management 2(1):282-300.

Yusnaena and Syahril. (2013). Pengaruh Integritas Terhadap Kinerja Karyawan Pada Sekertariat Daerah Kabupaten Pesisir Selatan. MENARA Ilmu 9 (42):186-91. 